\title{
The Physical and Morphological Characteristics of Mango Powder (Mangifera indica L. cv Tommy Atkins) Produced by Foam Mat Drying
}

\author{
Ana María Chaux-Gutiérrez ${ }^{1}$ • Ezequiel José Pérez-Monterroza ${ }^{1}$. \\ Vânia Regina Nicoletti Telis ${ }^{1} \cdot$ Maria Aparecida Mauro ${ }^{1}$
}

Received: 22 August 2016 / Accepted: 1 December 2016/Published online: 9 December 2016

(C) Springer Science+Business Media New York 2016

\begin{abstract}
The thermal behavior, moisture adsorption properties and structural and morphological characteristics of mango powders were evaluated. The powders were obtained by foam mat drying methodology using albumin (ALB), mixture (EB) of monoglycerides of fatty acids, sorbitan monostearate and polyoxyethylene sorbitan monostearate and a combination of the two (EB-ALB) as foaming agents. The evaluation was done by differential scanning calorimetry (DSC), X-ray diffraction (XRD) and scanning electron microscopy (SEM), and the moisture adsorption isotherms were also determined. The powder with EB had a glass transition temperature $\left(\mathrm{T}_{\mathrm{g}}\right)$ of $-4.2^{\circ} \mathrm{C}$. The denaturation temperature of pure albumin $\left(82.2^{\circ} \mathrm{C}\right)$ increased in the powders with ALB to $117^{\circ} \mathrm{C}$ and in those with EB-ALB to $102{ }^{\circ} \mathrm{C}$, due to the thermal stability provided by the pulp sugars. The moisture sorption isotherm of the EB-powder showed a higher water equilibrium content than the other powders. All the powders were in the amorphous state. The morphology of the powder with EB showed corrugated particles, whereas those with ALB and EB-ALB showed particles with a less porous aspect and more compact surfaces than the powders with EB.
\end{abstract}

Keywords Moisture adsorption - Glass transition temperature $\cdot$ Albumin $\cdot$ X-ray diffraction $\cdot$ Sorbitan monostearate $\cdot$ Emulsifier

Ana María Chaux-Gutiérrez

anachauxg@gmail.com; anachaux@ibilce.unesp.br

1 Department of Food Engineering and Technology; Institute of Bioscience, Language and Physical Sciences (IBILCE), UNESPSão Paulo State University, Rua Cristovão Colombo 2265, São José do Rio Preto, SP 15054-000, Brazil

\section{Introduction}

The mango (Mangifera indica $\mathrm{L}$ ) is an agricultural product that stands out for its nutritional value, being considered a source of antioxidants, constituted of $\beta$-carotene, which is a precursor of vitamin $\mathrm{A}$, vitamin $\mathrm{C}$ and phenolic compounds [1]. However mango is a perishable product and can deteriorate in a short period of time, hence the production of dehydrated mango powder is an important alternative in the production chain $[2$, 3]. Foam mat drying is one of the methodologies used to obtain powdered products, and consists of the production of a stable foam which can then be dried by several methods such as vacuum, microwave, freeze-drying and hot airflow, the latter being the most common method [4]. This technology has been used with success due to the short processing times and maintenance of the nutritional and organoleptic qualities of the final product [4-6]. The functional properties of the food powders are strongly dependent on the particle characteristics, more particularly their surface properties, which are a result not only of the processing steps involved in their manufacture, but also external factors such as relative humidity, which can modify the characteristics required for storage, flow, agglomeration, dispersion or dissolution $[7,8]$.

Knowledge of the adsorption phenomenon, thermal behavior and structural and morphological characteristics is of great importance to determine the changes subsequent to the drying process and thus define the best conditions for storage and powder production $[9,10]$. In order to predict the interactions between the moisture and the surface area, the adsorption isotherms can be used as a tool to explain the relationship between the water activity and equilibrium moisture content of the product, which is related to storage stability $[11,12]$. One can also use the thermal analysis to determine first and second order transitions that can be occurring in the dry product, such as phase changes, protein 
denaturation and glass transition $\left(\mathrm{T}_{\mathrm{g}}\right)$, which are important as measurements of physicochemical deterioration and of the product shelf life [13]. Studies related to foam mat drying have targeted modeling of the drying process, optimization of the process conditions and the evaluation of the physical, chemical and sensory attributes of the products, and little research has centered on a study of the adsorption properties and $\mathrm{T}_{\mathrm{g}}[4,6,14-19]$. Considering the importance of the requirements for quality in the manufacture and storage of food powders, the objective of the present study was to determine the thermal behavior, moisture adsorption properties and the structural and morphological characteristics of mango powders dehydrated by foam mat drying and evaluate the influence of the foaming agents ALB and EB on these properties.

\section{Materials and Methods}

\section{Materials}

The mangos (Mangifera indica L) cv. "Tommy Atkins" were acquired from the State Supply Center (CEAGESP) in São José do Rio Preto (São Paulo, Brazil), and maintained at room temperature until ripe. Ripeness was determined visually by observation of the red-yellow color of the fruits and a firm consistency to the touch. The pulp obtained was packed into high density polyethylene bags and stored in a freezer at $-18{ }^{\circ} \mathrm{C}$ until used. Commercial albumin powder (ALB) (Naturovos, Salvador do Sul, RS, Brazil) and a commercial grade mixture (EB) of the monoglycerides of fatty acids, sorbitan monostearate and polyoxyethylene sorbitan monostearate (Duas Rodas Industrial, Jaraguá do Sul, SC, Brazil) were used as the foaming agents.

\section{Obtaining the Pulp, Foam Preparation and Drying}

The frozen mango pulp was placed in a refrigerator for $24 \mathrm{~h}$. To make the foams, $300 \mathrm{~g}$ of pulp was weighed and mixed with ALB (10 kg albumin $\cdot 100 \mathrm{~kg}^{-1}$ pulp), or EB (2 $\mathrm{kg}$ emulsifier blend $\cdot 100 \mathrm{~kg}^{-1}$ pulp) or with the EBALB mixture $\left(2 \mathrm{~kg}\right.$ emulsifier blend. $100 \mathrm{~kg}^{-1}$ pulp plus $10 \mathrm{~kg}$ albumin $\cdot 100 \mathrm{~kg}^{-1}$ pulp). The foams were prepared by beating the mixtures in a domestic mixer (Philips Walita, Brazil) for $5 \mathrm{~min}$, the first minute being used to dissolve the foaming agents by beating at medium speed, and the rest of the time at high speed to incorporate air. The foam produced was placed in the bed of a fixed bed dryer to give a thickness of $3 \mathrm{~mm}$ and dried by forced air convection at $80^{\circ} \mathrm{C}$, the air being heated by electric resistances, whose temperatures were controlled by a digital microprocessor controller (N440, Novus, Porto Alegre, RS, Brazil) with a J-type thermocouple sensor. A centrifugal ventilator, regulated by a frequency inverter (CWF10, WEG, Jaguará do Sul, SC, Brazil) was used to maintain the air velocity at $1.0 \mathrm{~m} \cdot \mathrm{s}^{-1}$.

\section{Adsorption Isotherms}

The adsorption isotherms were determined by a gravimetric method using seven saturated aqueous salt solutions $(\mathrm{LiCl}$, $\mathrm{CH}_{3} \mathrm{COOK}, \mathrm{MgCl}_{2}, \mathrm{~K}_{2} \mathrm{CO}_{3}, \mathrm{NaBr}, \mathrm{NaNO}_{2}$ and $\mathrm{NaCl}$ (Synth, Labsynth, Diadema, SP, Brazil), in order to obtain relative humidity values between 11.3 and $75.1 \%$. Two to $3 \mathrm{~g}$ of powder were weighed into previously sanitized capsules, placed in glass jars, hermetically closed and stored in a B.O. D incubator (T 71, Simétrica, Piracicaba, SP, Brazil) with the temperature controlled at $30{ }^{\circ} \mathrm{C}$. The samples were weighed weekly on an analytical balance (AUX 220, Shimadzu, Japan) to constant mass. The criterion established for equilibrium was when the maximum variation between two consecutive weighings was equal or less than $0.1 \%$. The moisture content was determined after reaching equilibrium. The experimental data were fitted to the Guggenheim, Anderson, and de Boer (GAB) Eq. (1), which showed the equilibrium moisture behavior $\left(X_{\text {eq }}\right)$ on a dry weight basis $\left(\mathrm{kg} \cdot \mathrm{kg}^{-1}, \mathrm{dwb}\right)$ as a function of the water activity $\left(a_{w}\right)[20]$.

\section{GAB Model}

$X_{e q}=\frac{X_{m} \cdot C \cdot K \cdot a_{w}}{\left(1-K \cdot a_{w}\right)\left(1-K \cdot a_{w}+C \cdot K \cdot a_{w}\right)}$

$X_{m}$ is the moisture content of the monolayer $\left(\mathrm{kg} \cdot \mathrm{kg}^{-1}\right.$, $\mathrm{dwb})$. $\mathrm{C}$ and $\mathrm{K}$ are parameters calculated as from the fit of the experimental data. The goodness of fit was evaluated using the coefficient of determination $\left(R^{2}\right)$, the smallest chisquared value $\left(\chi^{2}\right)$, and a percent mean relative error $P(\%)$ $<10$ according to the Eqs. (2) to (4), respectively, using the Statistic 7.0 software (StatSoft Inc. South America, Tulsa, OK, USA).

$$
\begin{gathered}
R^{2}=\sqrt{\frac{\sum_{i=1}^{N}\left(X_{e i}-X_{c i}\right)^{2}}{\sum_{i=1}^{N}\left(X_{e i}-X_{c i}\right)^{2}}} \\
\chi^{2}=\sqrt{\frac{\sum_{i=1}^{N}\left(X_{e i}-X_{c i}\right)^{2}}{N-n}}
\end{gathered}
$$


$P=\frac{100}{N} \sum_{i=1}^{N} \frac{\left|X_{e i}-X_{c i}\right|}{X_{e i}}$

where $\overline{X_{e i}}$ is the mean of the observed values, $X_{c i}$ and $X_{e i}$ are the calculated and experimental values for moisture content, $N$ is the number of experimental data and $\mathrm{n}$ is the number of parameters.

\section{Surface Area of Sorption and Pore Size of Mango Powders}

The surface area de sorption $\left(S_{0}\right)$ was determined from the monolayer moisture $\left(X_{m}\right)$ according to Eq. (5) [12].

$S_{o}=X_{m} \frac{1}{M_{w}} N_{o} A_{H_{2} O}=3.5 \times 10^{3} X_{m}$

where $M_{w}$ is the molecular weight of water $\left(\mathrm{kg} \cdot \mathrm{mol}^{-1}\right), N_{o}$ is the Avogadro number $\left(6.0 \times 10^{23}\right.$ molecules $\left.\cdot \mathrm{mol}^{-1}\right)$ and $A_{H 2 O}$ is the area of a water molecule $\left(1.06 \times 10^{-19} \mathrm{~m}^{2}\right)$.

The average pore size was determined according to Singh et al. [21] by using the Kelvin and Hasley equations. The Kelvin equation is given by Eq. (6):

$\gamma_{k}=\frac{-2 \sigma \bar{v}}{R T \ln a_{w}}$

where $\gamma_{k}=$ Kelvin Radius (m), $\sigma=$ surface tension of water $(\mathrm{N}$. $\left.\mathrm{m}^{-1}\right), \bar{\nu}=$ molar volume of sorbate in this bulk liquid condition $\left(\mathrm{m}^{3} \cdot \mathrm{mol}^{-1}\right), R=$ universal gas constant $\left(\mathrm{kJ} \cdot \mathrm{mol}^{-1} \cdot \mathrm{K}^{-1}\right), T=$ absolute temperature (K) and $a_{w}=$ water activity.

The Kelvin equation is applied frequently to predict the pore size in the condensation region of the isotherm. In addition, the thickness of the adsorbed layer of water condensed was calculated from the Halsey equation Eq. (7):

$t=0.354\left(\frac{-5}{\ln a_{w}}\right)^{1 / 3}$

where $t$ is the thickness of the adsorbed water multilayer (nm) and $a_{w}$ is the water activity.

The effective average pore size, $R p(\mathrm{~nm})$ can be calculated as follows:

$R_{p}=\gamma_{k}+t$

\section{Moisture Content}

The moisture contents of the mango powders were determined gravimetrically in triplicate by drying the samples in a vacuum oven (TE-395, Tecnal, Piracicaba, SP, Brazil) at $60{ }^{\circ} \mathrm{C}$ and $10 \mathrm{kPa}$ to constant weight [6].

\section{Differential Scanning Calorimetry (DSC)}

Differential scanning calorimetry was carried out using a Perkin Elmer DSC 8000 calorimeter (PerkinElmer Corp, Shelton, CT, USA) previously calibrated with Indium. An empty aluminum pan was used as reference. The samples were previously conditioned to a relative humidity of $11.3 \%$ using a saturated lithium chloride solution at $30^{\circ} \mathrm{C}$. Between 2 and $3 \mathrm{mg}$ of sample were weighed, cooled from 25 to $-50^{\circ} \mathrm{C}$ at $35^{\circ} \mathrm{C} \cdot \mathrm{min}^{-1}$, maintained at this temperature for $1 \mathrm{~min}$, and subsequently heated at $35^{\circ} \mathrm{C} \cdot \mathrm{min}^{-1}$ from -50 to $200^{\circ} \mathrm{C}$. The Perkin Elmer Pyris software, version 10.0 (Perkin Elmer Inc., Shelton, CT, USA) was used to calculate the melting point $\left(T_{m}\right)$, denaturation temperature $\left(T_{d}\right)$, the enthalpies $(\Delta H)$ associated with the first order transitions and the glass transition temperature $\left(\mathrm{T}_{\mathrm{g}}\right)$. The analyses were carried out in duplicate.

\section{X-Ray Diffraction}

The X-ray diffraction patterns were determined using a diffractometer RINT 2000 (Rigaku, Tokio, Japan) operating with a voltage of $45 \mathrm{kV}$ and current of $30 \mathrm{~mA}$. The diffractograms were taken between $5^{\circ}$ and $50^{\circ}(2 \theta)$, with step sizes of $0.02^{\circ}$ and a scan rate of $1 \mathrm{~s}$ per step [2].

\section{Scanning Electron Microscopy (SEM)}

SEM was used to visualize the morphology of the mango powders with EB, ALB and EB-ALB, which were coated with gold in a sputter under vacuum for $3 \mathrm{~min}$. The images were made using a scanning electron microscope (JSM7500F, FEG-MEV JEOL, Germany).

\section{Results and Discussion}

\section{Adsorption Isotherms}

Figure 1 shows the adsorption isotherms $\left(30^{\circ} \mathrm{C}\right)$ of the mango powders obtained with EB, ALB and EB-ALB. It can be seen that the equilibrium moisture content of the powder with $\mathrm{EB}$ tended to be higher than those of the powders with ALB and EB-ALB. Specifically, on comparing the three powders at a water activity of 0.75 , the equilibrium moisture content of the EB powder was significantly higher $(p<0.05)$. This could be related to the fact that the powder with EB contained more sugar on a dry weight basis, than the other powders. It was observed that the addition of ALB decreased the sugar proportion to approximately two thirds of the proportion that found in original mango pulp. In dry products the relationship between moisture adsorption and sugars becomes important at intermediate and high water activities, resulting in an 


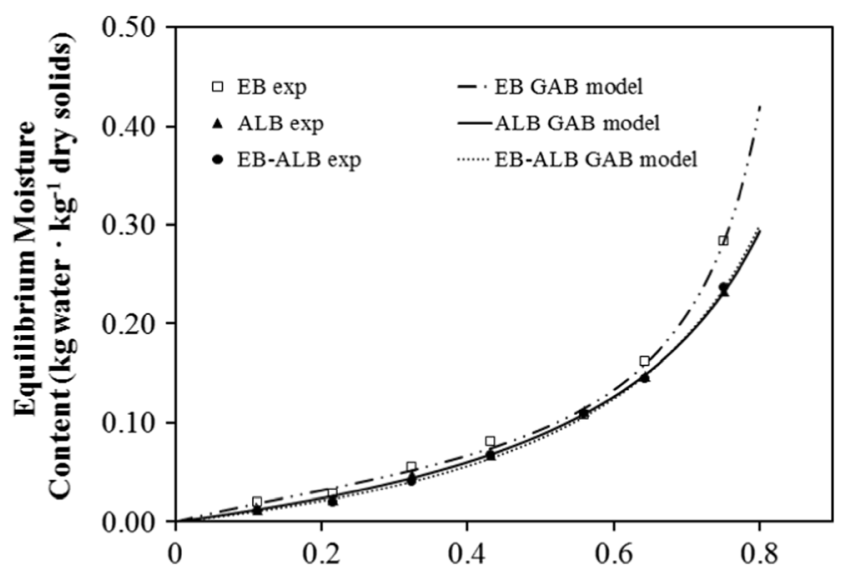

Fig. 1 Adsorption isotherms of mango pulp powders foam mat dried at $30{ }^{\circ} \mathrm{C}$

accentuated increase in moisture adsorption as the water activity rises, due to the predominant effect of solute-solvent interactions associated with sugar dissolution [22, 23]. In addition, the higher equilibrium moisture content reached by the powder with EB could also be attributed to the affinity of sorbitan monostearate and polyoxyethylene sorbitan monostearate for water, as demonstrated by the high value of its hydrophilic lipid balance (HLB) [24].

On the other hand, the powders with ALB and EB-ALB showed a smaller equilibrium moisture content than the powder with only EB, which could be associated with the characteristics of the protein, which has less water holding capacity [25] than sugars [26]. Hernández et al. [27] suggested that the amount of moisture adsorbed by a protein and polysaccharide mixture decreased with an increase in protein content, due to the less hydrophilic nature of protein as compared to polysaccharides. The low equilibrium moisture content of the powder with EB-ALB was also associated to a higher proportion of protein present in the mango powder, which probably saturated on its surface, avoiding that the emulsifiers with a greater hydrophilicity interact with the water molecules; this resulted in a decrease in the moisture adsorption. Jayasundera et al. [28] studied the amount of proteins and low molecular weight surfactants required to produce amorphous sugar powders through spray dry, suggesting that proteins can migrate to an air-water interface forming a layer that does not allow the emulsifiers to occupy the surface.

The effect of some additives on the moisture adsorption behavior of fruit powders has been reported in the literature. Mosquera et al. [22] found that the addition of maltodextrin affected the moisture adsorption capacity of freeze dried Borojó pulp (Borojoa patinoi Cuatrec.), which was less hygroscopic than the pulp without additive. Jakubczyk et al. [18] also reported that the addition of maltodextrin to foams produced from apple pulp, albumin and methylcellulose and subsequently freeze dried, reduced the equilibrium moisture values.
The behavior observed for the sorption isotherms of the mango powders (Fig. 1) coincided with that found for most food products, represented by sigmoidal type curves, and also with the behavior associated with sugar-rich foods, represented by exponential curves [29]. According to the Brunauer classification, the isotherm of the powder with EB showed a type II sigmoidal behavior [30], with a slight inflection near the $a_{w}$ of 0.4 , after which a sharp increase was observed, which is characteristic of hygroscopic products [23]. Conversely, the inflection was almost imperceptible for the powders with ALB and EB-ALB, characterizing isotherms between types II and III.

Jakubczyk et al. [18] reported that for apple puree foam containing albumin, methylcellulose and maltodextrin, followed by convective air-drying, microwave-drying or freeze-drying, the isotherms were of type III, whereas Raharitsifa and Ratti [19] reported that the isotherms for apple juice foam prepared with albumin and dried by freeze-drying, showed type II behavior. These differences are related to the foam compositions and structure of the dry product, which is the result of the porosity obtained in the formation of the foam and the drying methodology. It should be noted that, pore radius and the surface area of sorption of the mango powders were calculated theoretically [21], according to Eqs. (6) to (8), and the results were ranged between 5 to $36 \mathrm{~nm}$ and 185.5 to $367.5 \mathrm{~m}^{2} \cdot \mathrm{g}^{-1}$ respectively, and can be classified as mesopores (2-50 nm) according to International Union of Pure and Applied Chemistry (IUPAC) [12].

The GAB model was selected for predictive purposes, since its parameters have physical meaning, and the function manages to represent the experimental data in the water activity range between 0.10 and 0.90 [31]. The value of the monolayer $\left(X_{m}\right)$ indicates the limit of the moisture adsorbed by the material and evaluates the physicochemical stability during storage in relation to lipid oxidation, enzymatic activity and the structural characteristics [23]. For the GAB model, the mango powders with EB, ALB and EB-ALB presented values for $X_{m}$ of $0.053,0.089$ and $0.110 \mathrm{~kg}$ water. $\mathrm{kg}^{-1} \mathrm{dwb}$, respectively. These results were similar to those reported by Zhao et al. [32] for freeze dried mango pulp $\left(0.109 \mathrm{~kg}\right.$ water $\cdot \mathrm{kg}^{-1}$ dwb), but higher than those reported by Tonon et al. [11] who obtained values for $X_{m}$ of 0.05 and $0.063 \mathrm{~kg}$ water $\cdot \mathrm{kg}^{-1} \mathrm{dwb}$, for acai juice dried by aspersion with 10 and 20 DE maltodextrin, and with gum Arabic and tapioca starch of between 0.032 and $0.053 \mathrm{~kg}$ water $\cdot \mathrm{kg}^{-1} \mathrm{dwb}$. These differences depend on the composition of the fruits and also on the type and amount of additives used or otherwise, in addition to the type of processing.

The parameter $\mathrm{K}$ represents the interactions between the molecules of moisture adsorbed by the multilayer with the adsorbent [12], and according to the results obtained, all the powders presented values for $\mathrm{K}$ close to 1 (Table 1 ). These results indicated that there were fewer interactions between 
Table 1 Parameters of the model fitted to the experimental data from the moisture adsorption isotherms at $30{ }^{\circ} \mathrm{C}$ of the mango powders obtained by foam mat drying

\begin{tabular}{lllll}
\hline Model & Parameters & EB & ALB & EB-ALB \\
\hline GAB & $X_{m}$ & 0.053 & 0.089 & 0.105 \\
& $\mathrm{C}$ & 3.078 & 1.173 & 0.841 \\
& $\mathrm{~K}$ & 1.099 & 0.951 & 0.937 \\
& $R^{2}$ & 0.998 & 0.999 & 0.994 \\
& $\chi^{2}$ & 0.009 & 0.006 & 0.010 \\
& $\% P$ & 6.772 & 6.587 & 6.905 \\
\hline
\end{tabular}

water molecules and the powders in the multilayer. On the other hand, the parameter $\mathrm{C}$ indicates the force of the bonding of the water molecules found in the monolayer [33]. In this study low values were obtained for parameter $\mathrm{C}$, this result suggests that the water molecules were not very strongly bound in the monolayer in the powders obtained. However it should be mentioned that the powders with EB showed a higher value for $\mathrm{C}$ than the powders with ALB and EB-ALB.

\section{Differential Scanning Calorimetry Analysis (DSC)}

Table 2 shows the thermal behaviors of the fresh mango pulp, the commercial grade foaming agents EB and ALB and of the powders obtained. A first order transition was observed in the fresh pulp at $1.3{ }^{\circ} \mathrm{C}$, which represents the $\mathrm{T}_{\mathrm{m}}$ of the freezable water present in the pulp. In addition, a second endotherm was found with a $T_{m}$ within the melting temperature range of the sugars present in the mango, such as sucrose, glucose and fructose [34], as reported by Ross [35] and Slade and Levine [36], and whose values were found in the ranges between 173 and 192, 143 and 158 and 133 and $115{ }^{\circ} \mathrm{C}$, respectively. This same second endotherm was also observed in the dry pulp (Table 2).

The powder with EB presented two endothermal events (Fig. 2b). The first corresponded to the melting of sorbitan monostearate and of the monoglycerides of fatty acids, which showed $\mathrm{T}_{\mathrm{m}}$ values in the range from 50 to $60{ }^{\circ} \mathrm{C}$ $[37,38]$. This was confirmed in the present work from the determination of the thermograms of pure EB (commercial grade), whose value was $57{ }^{\circ} \mathrm{C}$ (Table 2). The second endotherm was found between 134 and $162{ }^{\circ} \mathrm{C}$, the value being close to that found for the endotherms of the fresh and dried mango pulps. Thus it corresponds to the sugars present in the mango pulp, as mentioned earlier. It should be mentioned that the fresh pulp showed a higher melting enthalpy $\Delta \mathrm{H}_{\mathrm{m}}$ than the dried pulp, followed by the powder with EB (Table 2). This was due to the fact that the melting enthalpy increases with an increase in water content. In food with high water content like fresh pulp the first order transitions are fairly similar to those of pure water which have a high melting enthalpy [39]. The increase in melting enthalpy was also pointed out by Roos [40] in a study on freeze dried strawberry powder. The lower $\Delta \mathrm{H}_{\mathrm{m}}$ found in powder with EB in comparison with dried pulp is probably due to the fact that emulsifiers could act as the nucleating sites, with these nuclei decreasing the energy involved in the melting and crystallization, resulting in a decrease of the $\Delta \mathrm{H}_{\mathrm{m}}$. [39].

The powder with ALB only showed one endotherm, which was associated with the denaturation of albumin at a $\mathrm{T}_{\mathrm{d}}$ of $117.4{ }^{\circ} \mathrm{C}$, this value being higher than that found for the pure commercial grade ALB $\left(82.2{ }^{\circ} \mathrm{C}\right.$, Table 2). Kulmyrzaev et al. [41] suggested that thermal denaturation of proteins is affected by sugar presence such as sucrose. The sucrose concentration increases the thermal stability of proteins, due to decrease in the affinity for the water. Similarly, Lee and Timasheff [42] found that the effect of sucrose on the stabilization of the protein structure is related to the thermodynamic properties of the sucrose-water system. The sucrose stabilizes the globular proteins, since the unfolded state of the protein is thermodynamically less favorable in presence of sucrose. Carpenter and Crowe [43] suggested that the sugars could protect the dried proteins, because these sugars can bind to the protein during the final stages of drying process.

Similarly, Nafchi et al. [44], studying the influence of reducing and non-reducing sugars on the denaturation of ovalbumin, found that the value for $T_{d}$ increased slightly in the presence of fructose, glucose and sucrose, as observed for the powder with ALB. It should be noted that there are no endotherms in the region of the melting of the sugars in the pulp in the powders with ALB (Table 2), suggesting that the protein could minimize an eventual sugar crystallization during drying, due to the capacity of the sugars to form hydrogen bonds with proteins [43]. Kreilgaard et al. [45] reported that sucrose stabilized the lipase Humicola lanuginosa and underlined the fact that sucrose crystallization and damage to the protein could be minimized by decreasing the mass ratio of sucrose: protein.

The powder with EB-ALB showed a decrease in $T_{d}$ in relation to the value obtained for the powder with ALB. The presence of the monoglycerides of fatty acids, sorbitan monostearate and polyoxyethylene sorbitan monostearate also affected the thermal stability of the powder. The emulsifiers can act as both protein stabilizers and destabilizers, depending on their nature and concentration [46]. It should be pointed out that the $\mathrm{T}_{\mathrm{d}}$ found for the powder with ALB $\left(117.4{ }^{\circ} \mathrm{C}\right)$ was higher than that found for the powder with EB-ALB $\left(102.3{ }^{\circ} \mathrm{C}\right)$, showing a slight decrease in thermal stability in the presence of EB.

Glass transition temperatures were observed for the dry pulp and the powder with EB (Table 2), second order transitions being associated with the soluble solids 


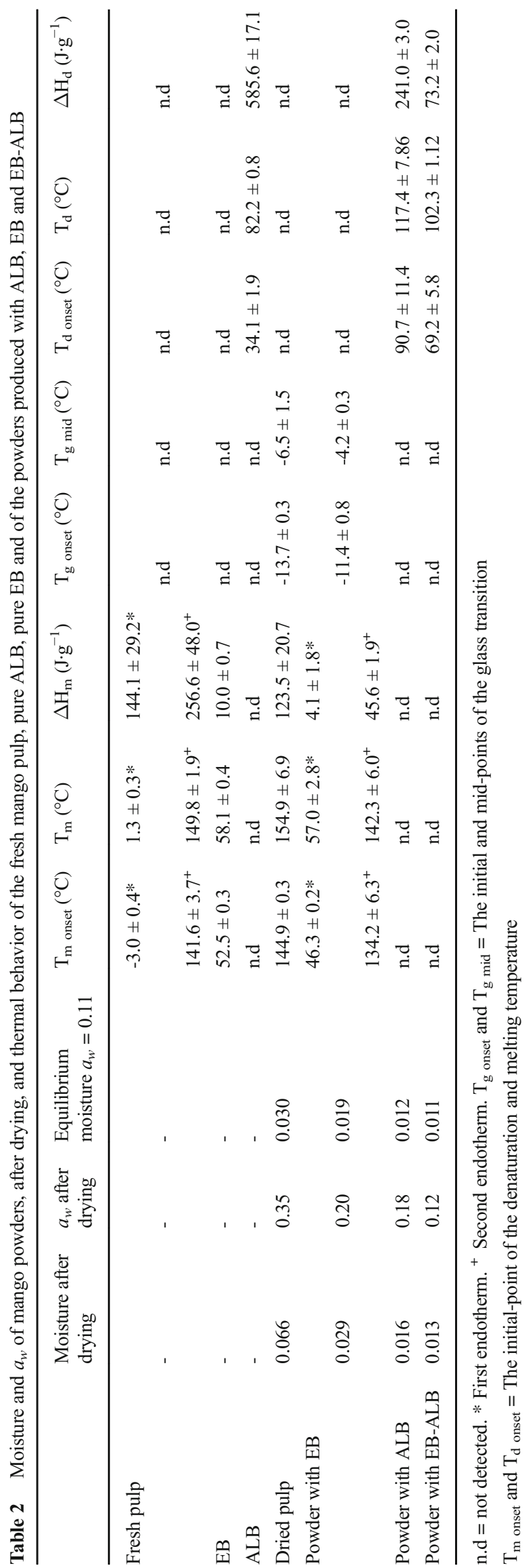

content, mainly sugars. As shown in the XRD analysis (Fig. 3a) these sugars were in the amorphous state. However, as described earlier, these powders showed an endotherm associated with their melting, which was attributed to the fact that, above the $\mathrm{T}_{\mathrm{g}}$ and a determined $a_{w}$ value, the amorphous solid could start to crystallize and subsequently show a melting endotherm [47, 48]. For an $a_{w}$ value of 0.11 , the $\mathrm{T}_{\mathrm{g}}$ of $-4.2{ }^{\circ} \mathrm{C}$ of the powder with $\mathrm{EB}\left(0.019 \mathrm{~kg}\right.$ water $\left.\cdot \mathrm{kg}^{-1} \mathrm{dwb}\right)$ (Fig. 2b) was slightly higher than the value found for the dry mango pulp, which was $-6.5{ }^{\circ} \mathrm{C}\left(0.030 \mathrm{~kg}\right.$ water $\left.\cdot \mathrm{kg}^{-1} \mathrm{dwb}\right)$, probably due to the plasticizing effect of the water. The higher the water content, the lower the $\mathrm{T}_{\mathrm{g}}$, whose effect is more pronounced when low molecular weight carbohydrates are present in the composition [47]. Syamaladevi et al. [49] showed a decrease in the $\mathrm{T}_{\mathrm{g}}$ of raspberry powder from $17.5^{\circ} \mathrm{C}$ to $-65.5^{\circ} \mathrm{C}$ when the moisture content rose from 0.034 to $0.242 \mathrm{~kg}$ water $\cdot \mathrm{kg}^{-1}$.

Zhao et al. [32] reported values for the $\mathrm{T}_{\mathrm{g}}$ of freeze dried mango pulp of between 19.7 and $-38.8{ }^{\circ} \mathrm{C}$ for moisture contents of between 0.010 and $0.14 \mathrm{~kg}$ water $\mathrm{kg}^{-1} \mathrm{dwb}$, respectively. Glass transition temperatures were not detected in powders containing ALB, which could be attributed to the fact that changes in the specific heat capacity are very small in sugarprotein systems, and are therefore difficult to detect, being masked on the thermogram [28].

\section{X-Ray Diffraction (XRD)}

Figure 3 shows the diffractograms of the mango powders produced with the different foaming agents. In general the mango powders presented diffraction patterns typical of the amorphous materials, similar to those found by Caparino et al. [2] in mango powders produced by Refractance Windows ${ }^{\circledR}$ drying and by freeze drying, as also as by Cano-Chauca et al. [50] for mango pulp spray dried with maltodextrin and Arabic gum as the carriers. The powders containing EB and EB-ALB (Fig. 3a,c) showed a peak with reflections in the Bragg angle at $21.5^{\circ}(2 \theta)$, which was attributed to material formed by sorbitan monostearate structures, whose value is approximately $21.3^{\circ}(2 \theta)$, as reported by Singh et al. [51]. Amorphous diffraction patterns can be explained by two factors. The first factor is related to the effect of proteins such as albumin on the decrease in crystallization of the sugars. During drying process, the presence of protein reduces the capacity of sugars to form intermolecular hydrogen bonds between themselves. This could be a result of the formation of hydrogen bonds between proteins and carbohydrates, which affecting the occurrence of crystallization [43]. The second factor is related to the fact that the foam mat drying process enhances water transport, due to high porosity and high effective diffusion coefficient $\left(D_{\text {eff }}\right)$ reached, which result in a decrease of the 
Fig. 2 Thermograms of the dry mango pulp (a) and of the powders with EB (b), ALB (c) and EB-ALB (d)
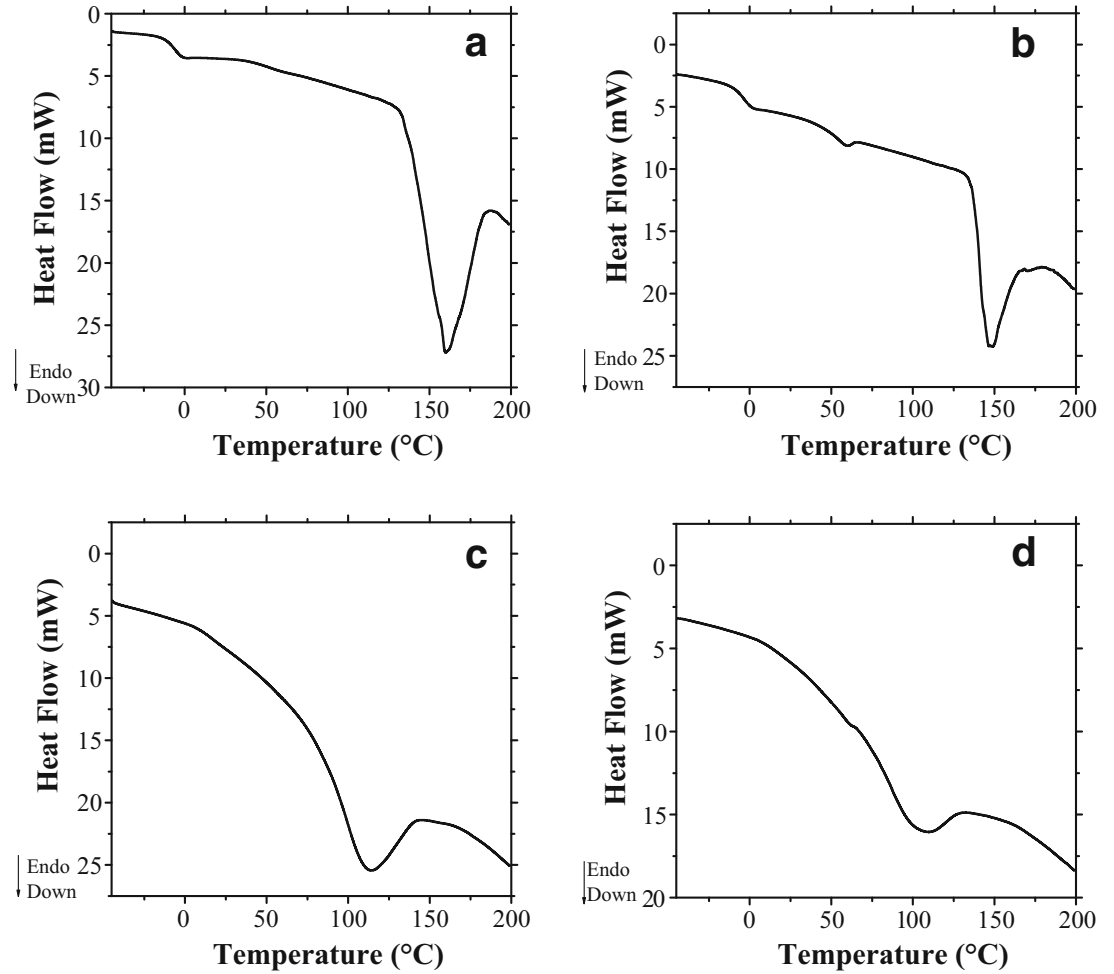

drying time, which does not allow the mango sugars (sucrose, fructose and glucose) to form crystalline structures. As reported in a previous study by Chaux-Gutiérrez et al.
[52], mango powders were obtained in processing times of about $2 \mathrm{~h}$, which were attributed to high effective diffusion coefficients $\left(D_{\text {eff }}\right)$. Similar results have also been found
Fig. 3 X-ray diffraction patterns of the mango powders with $\mathrm{EB}$ (a), ALB (b) and EB-ALB (c)
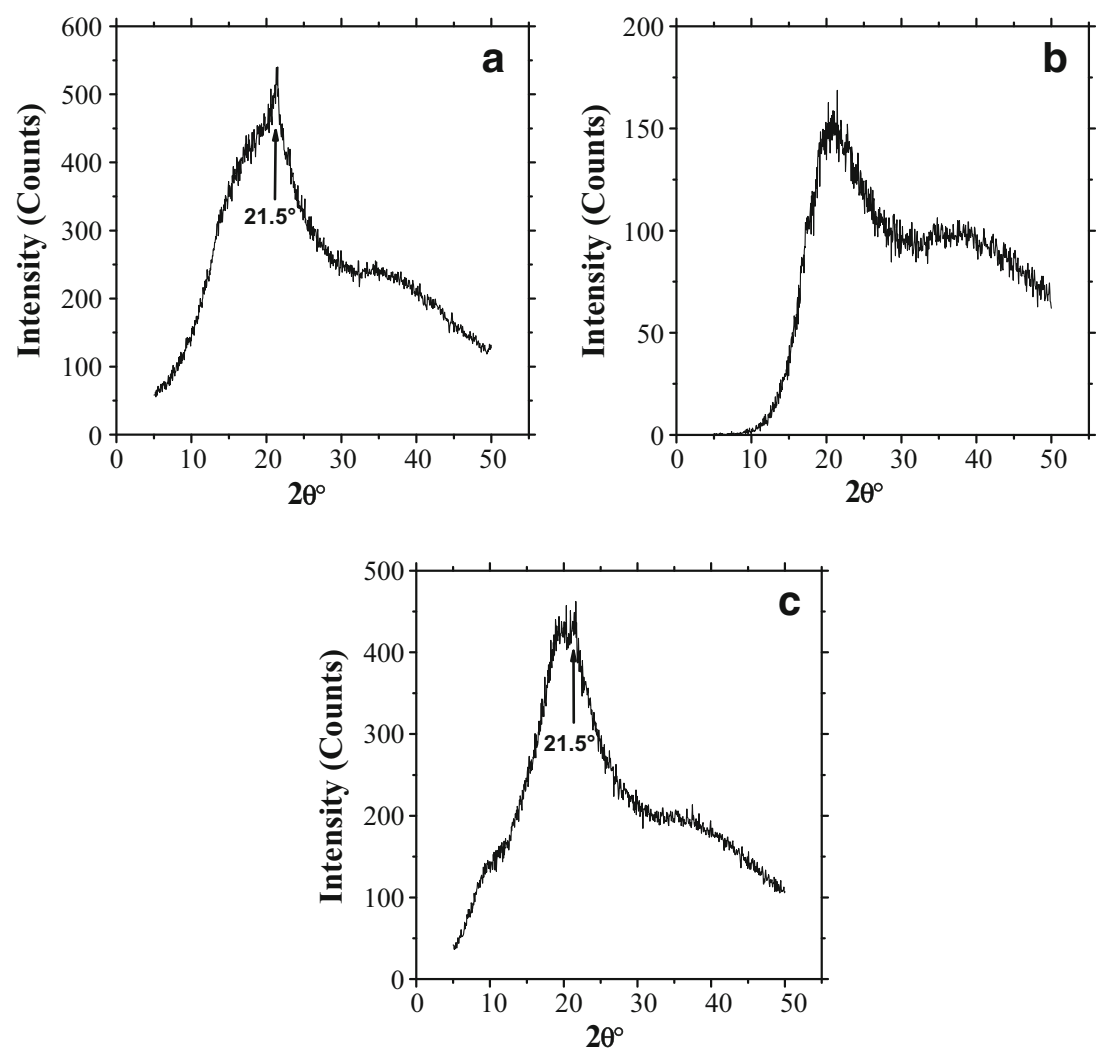
Fig. 4 SEM micrographs of the powders with $\mathrm{EB}(\mathbf{a}, \mathbf{b}$ and $\mathbf{c})$, $\mathrm{ALB}(\mathbf{d}, \mathbf{e}$ and $\mathbf{f})$ and EB-ALB $(\mathbf{g}, \mathbf{h}$ and $\mathbf{i})$ (magnification $100 \times(\mathbf{a}, \mathbf{d}, \mathbf{g}), 300 \times(\mathbf{b}, \mathbf{e}, \mathbf{h})$ and $60,000 \times(\mathbf{c}, \mathbf{f}, \mathbf{i})$
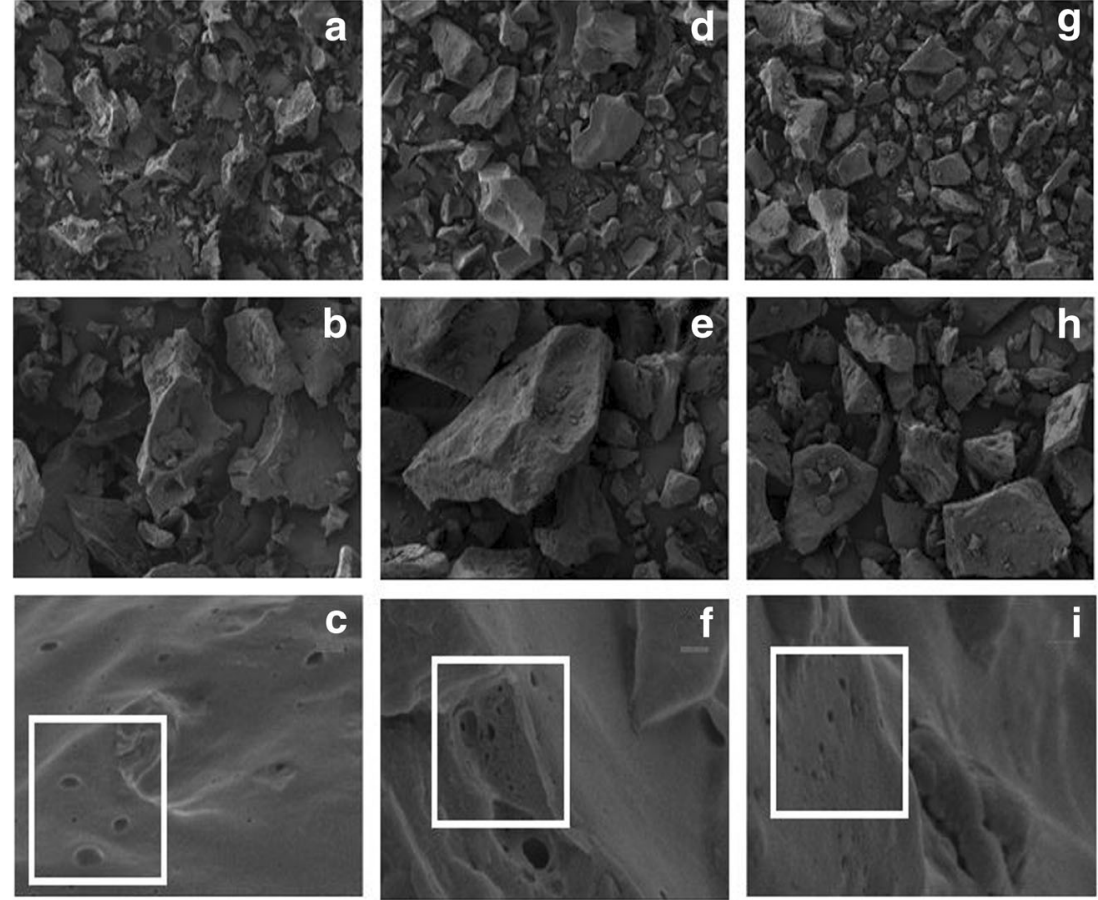

using the foam mat drying method [53, 54]. Caparino et al. [2] reported a similar behavior for dehydrated mango when using drum drying and spray drying processes.

\section{Scanning Electron Microscopy (SEM)}

Figure 4 shows the surfaces of the mango powder particles obtained by foam mat drying. In general, the powders obtained with EB (Fig. 4a,b) presented particles with a porous aspect and corrugated surface, possibly due to the low density of the foam formed with this additive, which, before drying, was $310 \mathrm{~kg} \cdot \mathrm{m}^{-3}$. On the other hand, the powder with ALB (Fig. 4d,e) showed particles with a denser morphological aspect than those made with EB, although small fragments of the material were also present, suggesting that the material crumbles with ease. Before drying, the density of this foam was $700 \mathrm{~kg} \cdot \mathrm{m}^{-3}$, and the surface of the particles with ALB was rougher than those with EB. The powder with EB-ALB (Fig. 4g,h) showed an aspect more similar to that of the particles with only ALB with more compact surfaces but a little more corrugated. The density of the foam before drying showed an intermediate value of $500 \mathrm{~kg} \cdot \mathrm{m}^{-3}$, as compared to the other two. In general, one could say that foam mat drying methodology produced a notably porous material (Fig. 4c-i) influenced by the addition of the foaming agents used. Thuwapanichayana et al. [54] reported that foams of low density could generate a dried matrix with a high amount of pores and larger size. No crystals were observed in any of the powders, confirming the results of the XRD.

\section{Conclusions}

This study evaluated the characteristics of the mango powders obtained by foam mat drying using EB and ALB as foaming agents. The ALB reduced the hygroscopicity and avoided the crystallization of the sugars in the mango powders. The mango powder prepared with EB-ALB showed physical and morphological characteristics similar to those obtained using only ALB. However, the presence of EB affected the mango powder thermal stability, causing a slight decrease in denaturation temperature of ALB. It is also worth mentioning that to use only EB as a foaming agent could cause second-order transition in the mango powder below room temperature, therefore further study is needed to determinate storage stability. According to the results obtained the ALB is a suitable foaming agent for producing dehydrated mango powder by foam mat methodology.

Acknowledgements The authors are grateful to the State of São Paulo Research Foundation (FAPESP) [grant numbers 2012/21428-6, 2014/11514-8], and to the Starch \& Breadmaking Laboratory UNESP-São José do Rio Preto, for allowing the authors to use the diffractometer, and to the LMA-IQ-UNESP-Araraquara for the use of the FEG-SEM facilities.

\section{References}

1. S. M. R. Ribeiro and A. Schieber, in Bioact. Foods Promot. Heal. Fruits Veg. (Elsevier, 2010), p. 507-523 
2. O.A. Caparino, J. Tang, C.I. Nindo, S.S. Sablani, J.R. Powers, J.K. Fellman, J. Food Eng. 111, 135 (2012)

3. V.R. Sagar, P. Suresh Kumar, J. Food Sci. Technol. 47, 15 (2010)

4. M. Azizpour, M. Mohebbi, M. Khodaparast, M. Varidi, Dry. Technol. 32, 374 (2014)

5. D.M. Kadam, R.A. Wilson, S. Kaur, Int. J. Food Prop. 15, $211(2012)$

6. A.A. Karim, C.C. Wai, Food Chem. 64, 337 (1999)

7. I. Murrieta-Pazos, C. Gaiani, L. Galet, R. Calvet, B. Cuq, J. Scher, J. Food Eng. 112, 1 (2012)

8. L.H. Mosquera, G. Moraga, P.F. de Córdoba, N. MartínezNavarrete, Food Biophys. 6, 397 (2011)

9. B. Bhandari, T. Howes, J. Food Eng. 40, 71 (1999)

10. K. Maleki Majd, S.H. Karparvarfard, A. Farahnaky, K. Jafarpour, Food Biophys. 8, 1 (2013)

11. R. Tonon, A. Baroni, C. Brabet, O. Gibert, D. Pallet, M. Hubinger, J. Food Eng. 94, 215 (2009)

12. S. Velázquez-Gutiérrez, A. Figueira, M. Rodríguez-Huezo, A. Román-Guerrero, H. Carrillo-Navas, C. Pérez-Alonso, Carbohydr. Polym. 121, 411 (2015)

13. B.P. Carter, S.J. Schmidt, Food Chem. 132, 1693 (2012)

14. K. Falade, N. Onyeoziri, Food Bioprocess Technol. 5, 879 (2010)

15. K. Falade, J. Okocha, Food Bioprocess Technol. 5, 1173 (2010)

16. P. Kandasamy, N. Varadharaju, S. Kalemullah, D. Maladhi, J. Food Sci. Technol. 51, 2526 (2012)

17. M.A. Karim, M.N.A. Hawlader, J. Food Eng. 70, 35 (2005)

18. E. Jakubczyk, E. Ostrowska-Ligeza, E. Gondek, Int. J. Food Sci. Technol. 45, 2515 (2010)

19. N. Raharitsifa, C. Ratti, J. Food Process Eng. 33, 341 (2010)

20. S. Rahman, Food properties handbook, 2nd edn. (CRC Press, Florida, 1995)

21. R.R.B. Singh, K.H. Rao, A.S.R. Anjaneyulu, G.R. Patil, Food Res. Int. 34, 143 (2001)

22. L.H. Mosquera, G. Moraga, N. Martínez-Navarrete, J. Food Eng. 97, 72 (2010)

23. J.M. Rodríguez-Bernal, E. Flores-Andrade, C. Lizarazo-Morales, E. Bonilla, L.A. Pascual-Pineda, G. Gutierréz-López, M.X. Quintanilla-Carvajal, Food Bioprod. Process. 94, 187 (2015)

24. B. Bergenståhl, in Food Emuls. Their Appl, 2nd edn., ed by G. Hasenhuettl, R. Hartel. (Springer, New York, 2008), pp. 173-190

25. H. Bull, Am. Chem. Soc. 66, 1499 (1944)

26. J. Chirife, C.F. Fontan, E.A. Benmergui, J. Food Technol. 15, 59 (1980)

27. G.H. Hernández, S. Livings, J.M. Aguilera, A. Chiralt, Food Hydrocoll. 25, 1311 (2011)

28. M. Jayasundera, B. Adhikari, T. Howes, P. Aldred, Food Chem. 128, 1003 (2011)
29. A. Al-Muhtaseb, W. McMinn, T. Magee, Trans IChemE 80, 118 (2002)

30. S. Brunauer, L. Deming, E. Deming, E. Teller, J. Am. Chem. Soc. 62, $1723(1940)$

31. E.O. Timmermann, J. Chirife, H.A. Iglesias, J. Food Eng. 48, 19 (2001)

32. J. Zhao, F. Liu, X. Wen, H. Xiao, Y. Ni, J. Food Eng. 157, 49 (2015)

33. E.J. Quirijns, A.J.B. Van Boxtel, W.K.P. Van Loon, G. Van Straten, J. Sci. Food Agric. 85, 1805 (2005)

34. J.N. Cruz, C.A. Soares, A.D.T. Fabbri, B.R. Cordenunsi, S.F. Sabato, Radiat. Phys. Chem. 81, 1059 (2012)

35. Y. Roos, Carbohydr. Res. 238, 39 (1993)

36. L. Slade, H. Levine, Crit. Rev. Food Sci. Nutr. 30, 115 (1991)

37. F. Peyronel, A.G. Marangoni, Food Res. Int. 55, 93 (2014)

38. G. Rizzo, J. Norton, I. Norton, Food Struct. Funct. Forum Symp. 4, 2 (2014)

39. Y. H. Roos, Phase Transitions in Foods (Academic Press, 1995)

40. Y. Roos, J. Food Sci. 52, 146 (1987)

41. A. Kulmyrzaev, C. Bryant, D.J. McClements, J. Agric. Food Chem. 48, $1593(2000)$

42. J. Lee, S.N. Timasheff, Biol. Chem. 256, 7193 (1981)

43. J.F. Carpenter, J.H. Crowe, Biochemistry 28, 3916 (1989)

44. M. Nafchi, R. Tabatabaei, B. Pashania, H. Rajabi, Int. J. Biol. Macromol. 62, 397 (2013)

45. L. Kreilgaard, S. Frokjaer, J.M. Flink, T.W. Randolph, J.F. Carpenter, J. Pharm. Sci. 88, 281 (1999)

46. T. Nylander, T. Arnebrant, M. Bos, P. Wilde, in Food Emuls. Their Appl edited by G. Hasenhuettl and R. Hartel, 2nd ed. (Springer, New York, 2008), pp. 89-156.

47. Y.H. Roos, J. Food Eng. 24, 339 (1995)

48. H.A. Iglesias, J. Chirife, M.P. Buera, J. Sci. Food Agric. 75, 183 (1997)

49. R.M. Syamaladevi, S.S. Sablani, J. Tang, J. Powers, B.G. Swanson, J. Food Eng. 91, 460 (2009)

50. M. Cano-Chauca, P.C. Stringheta, A.M. Ramos, J. Cal-Vidal, Innovative Food Sci. Emerg. Technol. 6, 420 (2005)

51. V.K. Singh, I. Banerjee, T. Agarwal, K. Pramanik, M.K. Bhattacharya, K. Pal, Colloids Surf. B: Biointerfaces 123, 582 (2014)

52. A. M. Chaux-Gutiérrez, A. B. Santos, D. M. Granda-Restrepo, M. A. Mauro, Dry. Technol. (2016)

53. R. Thuwapanichayanan, S. Prachayawarakorn, S. Soponronnarit, J. Food Eng. 86, 573 (2008)

54. A. Sangamithra, V. Sivakumar, J.S. Gabriela, K. Kannan, J. Food Process Eng. 1 (2015) 